\title{
Evaluation of Flooding in Sg Gita Catchment, Kuching
}

\author{
D.Y.S. Mah ${ }^{\mathrm{a}, *}$, C.P. Hii ${ }^{\mathrm{b}}$, C.Y. Ong ${ }^{\mathrm{b}}$ and Y. Pui ${ }^{\mathrm{b}}$ \\ ${ }^{a}$ Hydro-Environmental Engineering Research \& Development (HERD) Cluster, Department \\ of Civil Engineering, Faculty of Engineering, Universiti Malaysia Sarawak, 94300 Kota \\ Samarahan, Sarawak \\ ${ }^{b}$ Jurutera Adda Consulting Engineers, Bangunan USC, No 683, Lorong Song 1A, Off Jalan \\ Song, 93350 Kuching, Sarawak
}

\begin{abstract}
This paper outlines a methodology of flow routing with inclusion of downstream river water level applied to a Sg Gita urbanized catchment beside Sg Sarawak in Kuching city, Sarawak, Malaysia. Evaluations are done by demonstrating the modelling of flooding scenarios using InfoWorks River Simulation (RS) that stresses on different aspects specific to Sg Gita's conditions, namely (1) impacts of high and low river water levels, (2) solely urban flooding and (3) the combination of the two. The outcomes indicate that the dynamics of downstream river water level influences the performance of the urban drainage that flowed into the river. Backwater is overriding the flows of urban drains. Therefore, the mentioned methodology is found superior than conventional methodology with only flow routing to represent the flow mechanism of urban catchment bounded by a downstream river.
\end{abstract}

Keywords: backwater, InfoWorks RS, river water level, stormwater, urban drainage

\section{Introduction}

Sg Gita catchment is located immediate upstream of Satok Bridge (seen on the left of Figure 1). The area is one of the highly flood prone area in Kuching city beside Sg Maong catchment at the opposite bank [1],[2]. Its oldest settlement, Kpg Gita flanks a stretch of the northern bank of $\mathrm{Sg}$ Sarawak. As such, it suffered repeating flooding as reported in the major flood events in 2003, 2004 and 2009 [3]; as well as the recent 2013, 2015 and 2016.

\section{Rationale for flood investigation}

Before any flood mitigation measures could be prescribed to Kpg Gita, the cause of flooding at the area should be thoroughly scrutinized. This has become the intention of this paper to reconstruct a historical flood event to provide insights to the occurrence of flood. Evidenced in Figure 1, Sg Gita catchment has been heavily populated. Therefore, land drainage, in this case, the urban stormwater drainage is significant [4]; at the same time, due to the closeness to Sg Sarawak, the hydrology and hydraulics of the river also play a role.

\footnotetext{
* Corresponding author. Tel.: +6082-583207; fax: +6082-583410

E-mail address: ysmah@unimas.my

Manuscript History:

Received 28 January, 2017, Revised 26 April, 2017, Accepted 27 April, 2017, Published 28 April, 2017
}

ISSN: 2289-7771 


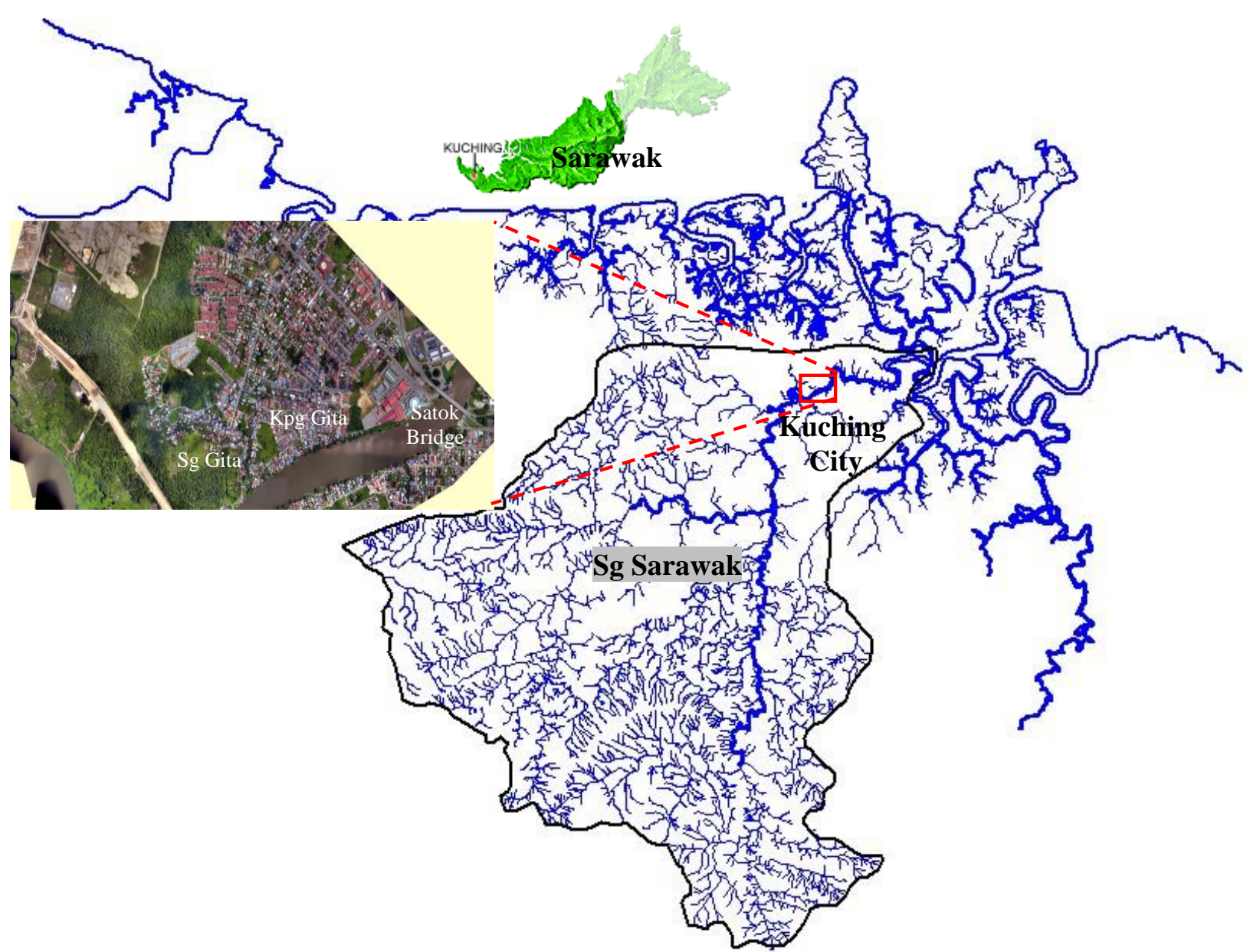

Figure 1. Sg Gita catchment.

To accommodate the said investigation, a computer simulation model is an appropriate tool to help animate the flooding processes [5]. The subject of modelling is a drainage system; and this drainage system of $\mathrm{Sg}$ Gita catchment has its outfalls pouring into Sg Sarawak. In addition, the river is regulated by the Kuching Barrage [6]. It implies that Sg Sarawak is controlled at rather constant water levels. During high tides, Kuching Barrage often closes its gates to stop tides from entering upstream river; yet if high rainfall events happened to coincide with high tide, it may cause the river water levels to soar to bank bursting levels [6]. Under such circumstances, the stormwater system would cease to have free-flowing outfalls but influenced by high river water levels.

Conventional simulation of ground surface runoff along a waterway involves various methods of flow routing. Solving the conservation of mass together with conservation of momentum allowing these methods to carry water from one point to a downstream point [7]. Usually, an upstream hydrograph is routed and a downstream hydrograph is computed as the result. However, downstream fluctuating water levels could not be accounted for in these methods. Then, these methods would represent poorly the field conditions of Kpg Gita.

InfoWorks RS, on another hand, simulates flow by defining both the upstream and downstream boundary conditions. The dynamics of river water levels could be represented in the latter. Although the name of the software suggests river, InfoWorks RS can model many forms of waterway, including the urban drain. Therefore, InfoWorks RS is chosen for this modelling task. 


\section{Modelling approach}

InfoWorks RS generally involves the following three (3) steps (see Figure 2). First, the source of water should be dealt with. As rainwater enters the urban environment, the geography of the location is playing an important role. Therefore, ground surface information is necessary. InfoWorks RS requires the information in the form of Ground Model.

Once landed, running water travels on the ground surface. The mechanism of running water could be simulated provided that the drainage network of its dimensions, invert levels and directions of flow are available. The necessary information has been collected by field surveys. The data are treated as inputs to the InfoWorks RS environment.

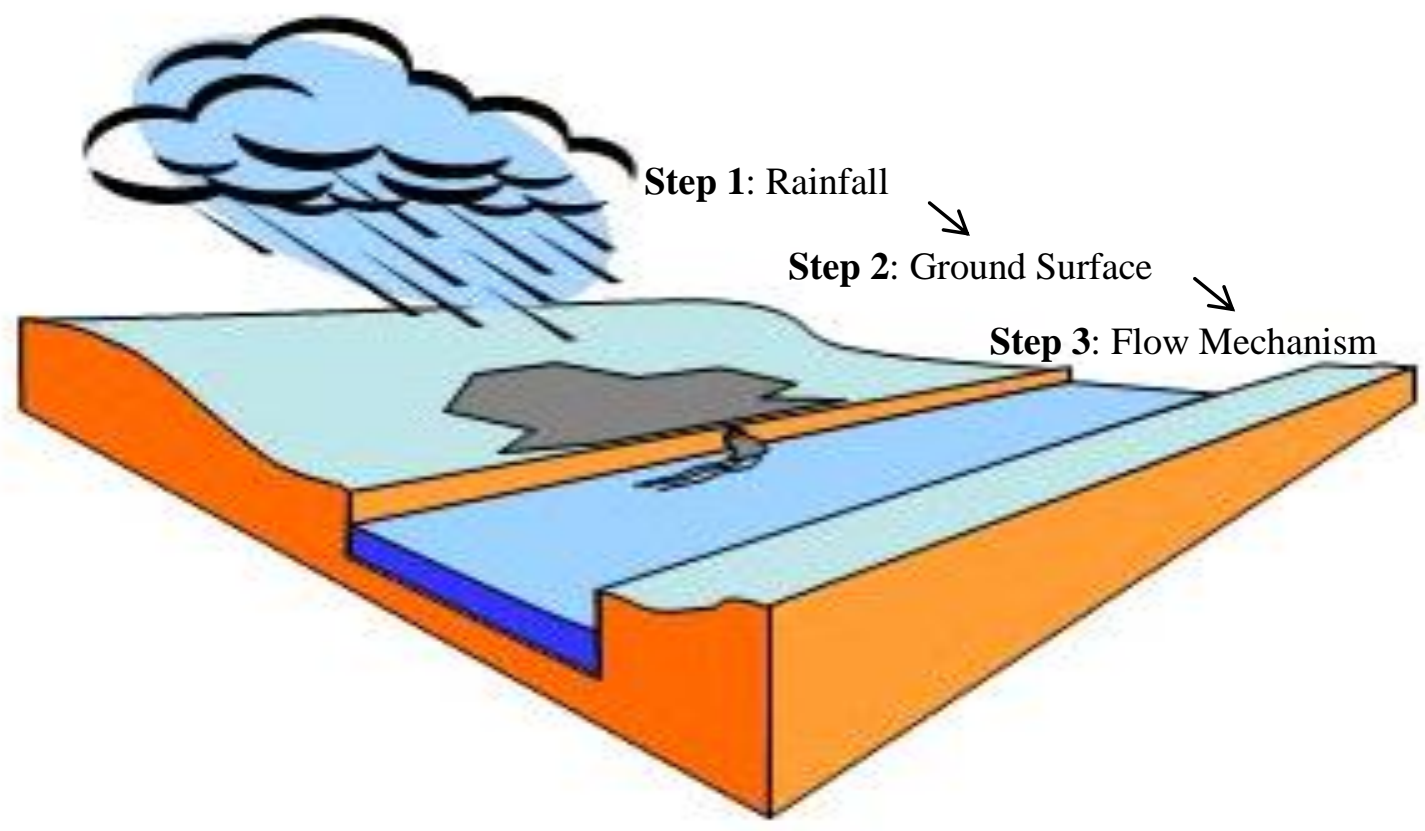

Figure 2. Modelling approach.

\subsection{Rainfall}

A historical event is selected to produce a reliable analysis. A most recent extreme storm event which occurred on $27^{\text {th }}$ February 2016 is selected for the purpose. The storm had the meteorological station in Kuching Airport to record a total rainfall of $141.5 \mathrm{~mm}$ spanning over thirteen hours. Table 1 shows the hourly rainfall on $27^{\text {th }}$ February 2016 recorded around Kuching and Figure 3 indicates the isohyetal map of the storm event. Note that $\mathrm{Sg}$ Gita catchment (encircled in the said figure) is close to the storm eye. Not surprisingly, Sg Gita catchment was flood stricken after the storm. 
Table 1 . Hourly rainfall on $27^{\text {th }}$ Feb 2016 around Kuching [8]

\begin{tabular}{|c|c|c|c|c|c|c|c|c|c|c|c|c|c|c|c|c|c|c|c|c|c|c|c|c|c|}
\hline \multicolumn{26}{|c|}{ Hourly Rainfall on 27.02.2016 } \\
\hline No & Station Name & $0: 00$ & 1:00 & $2: 00$ & $3: 00$ & $4: 00$ & $5: 00$ & $6: 00$ & $7: 00$ & $8: 00$ & $9: 00$ & $10: 00$ & 11:00 & $12: 00$ & $13: 00$ & 14:00 & 15:00 & $16: 00$ & $17: 00$ & 18:00 & 19:00 & 20:00 & $21: 00$ & 22:00 & $23: 00$ \\
\hline 1 & Bako Causeway & 0 & 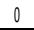 & 0 & 0 & 1 & 15.5 & 36.5 & 43.5 & 79.5 & 29 & 7.5 & 13 & 0.5 & 1.5 & 0 & 0 & 0 & 0 & 0 & 0 & 0 & 0 & 0 & 0 \\
\hline 2 & Batu Kawa Bridge & 0 & 0 & 0 & 0 & 33 & 27 & 17 & 5 & 16 & 6.5 & 6 & 3 & 1.5 & 0 & 0 & 0 & 0 & 0 & 0 & 0 & 0 & 0 & 0 & 0 \\
\hline 3 & Kampung Nelayan & 0 & 0 & 0.5 & 0.5 & 5 & 23 & 41.5 & 62.5 & 31.5 & 22.5 & 20.5 & 6 & 0 & 0 & 0 & 1 & 0 & 0 & 0 & 0 & 0 & 0 & 0 & 0 \\
\hline 4 & Kuching Airport & 0 & 0 & 0.5 & 2.5 & 24.5 & 21.5 & 42.5 & 24 & 6 & 7 & 5 & 4.5 & 3 & 0.5 & 0 & 0 & 0 & 0 & 0 & 0 & 0 & 0 & 0 & 0 \\
\hline 5 & Kuching City South & 0 & 0 & 0.5 & 3.5 & 3.5 & 15.5 & 82 & 85.5 & 51.5 & 27 & 32.5 & 22.5 & 0 & 0 & 0 & 0 & 0 & 0 & 0 & 0 & 0 & 0 & 0 & 0 \\
\hline 6 & Kuching Seberkas & 0 & 0 & 1.5 & 6 & 8 & 12 & 43 & 67.5 & 42 & 14.5 & 27 & 26.5 & 1.5 & 0 & 0 & 0 & 0 & 0 & 0 & 0 & 0 & 0 & 0 & 0 \\
\hline 7 & Kuching Third Mille & 0 & 0 & 1 & 7 & 13 & 11 & 55 & 67 & 41 & 16 & 27 & 21 & 0.5 & 0 & 0 & 0 & 0 & 0 & 0 & 0 & 0 & 0 & 0 & 0 \\
\hline 8 & Mallihah & 0 & 0 & 0 & 2 & 20 & 65.5 & 40 & 9.5 & 14.5 & 8 & 12 & 4 & 2.5 & 0 & 0 & 0 & 1 & 0 & 0 & 0 & 0 & 0 & 0 & 0 \\
\hline 9 & Maong Tengah Kin & 0 & 0 & 3.5 & 8.5 & 9.5 & 4 & 59 & 46 & 37 & 13 & 18 & 30.5 & 1.5 & 0 & 0 & 0 & 0 & 0 & 0 & 0 & 0 & 0 & 0 & 0.5 \\
\hline 10 & Mid Sungai Kuap & 0 & 0 & 0.5 & 5 & 26 & 26 & 15 & 50 & 5.5 & 10.5 & 27.5 & 23 & 2 & 0 & 0 & 0 & 0 & 0 & 0 & 0 & 0 & 0 & 0 & 0 \\
\hline 11 & Sebubut & 0 & 0 & 2 & 16 & 3 & 49.5 & 48 & 31.5 & 12 & 7 & 17 & 7.5 & 4 & 0 & 0 & 0 & 0 & 0 & 0 & 0 & 0 & 0 & 0 & 0 \\
\hline 12 & Semariann Fisheries & 0 & 0 & 0.5 & 0 & 0.5 & 3.5 & 45.5 & 25.5 & 30.5 & 30.5 & 23 & 3 & 0.5 & 0 & 0 & 0 & 0 & 0 & 0 & 0 & 0 & 0 & 0 & 0.5 \\
\hline 13 & Sioll.PS & 0 & 0 & 0.5 & 3.5 & 2 & 2.5 & 44 & 46 & 56.5 & 35.5 & 10 & 5.5 & 0 & 0 & 0 & 0 & 0 & 0 & 0 & 0 & 0 & 0 & 1.5 & 0.5 \\
\hline 14 & Sungai Tengah & 0 & 0 & 0 & 12 & 5.5 & 37.5 & 22 & 8 & 4 & 4 & 6.5 & 3 & 1.5 & 0 & 0 & 0 & 0 & 0 & 0 & 0 & 0 & 0 & 0 & 0 \\
\hline
\end{tabular}

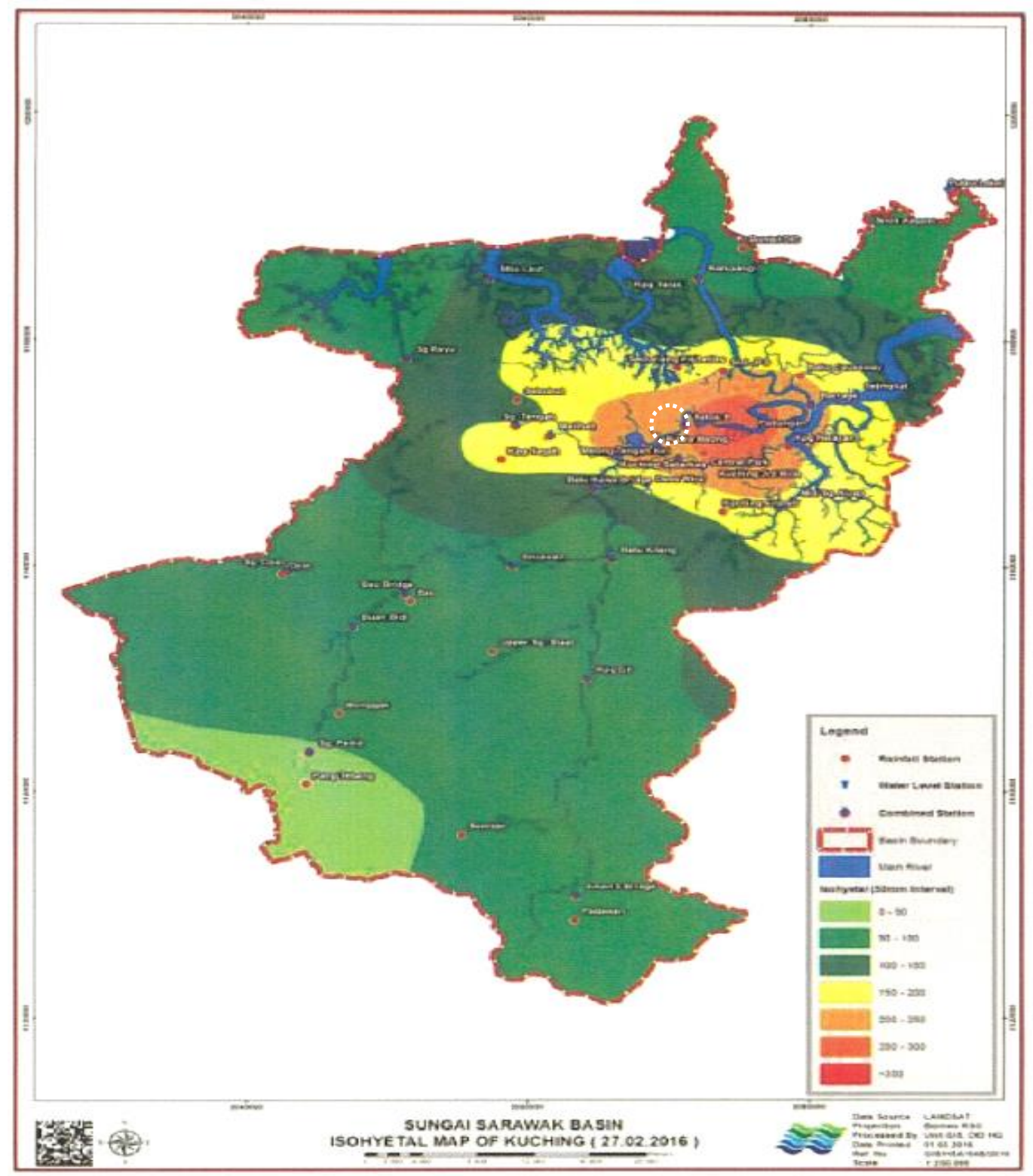

Figure 3. Isohyetal map of $27^{\text {th }}$ Feb 2016 storm event.[8] 


\subsection{Ground surface}

Floodplain survey by means of UAV drone [9] had enabled the computation of Digital Elevation Model (DEM) for Sg Gita catchment. Presented in Figure 4 is the mentioned DEM with elevations ranging from -1 to $9 \mathrm{~m}$ MSL. It can be said that the low laying areas below $5 \mathrm{~m}$ MSL in the study area are well captured.

A look into the DEM reveals that the northern part (Matang) is of higher elevations $(7-9 \mathrm{~m}$ MSL). Kpg Gita is generally situated on 5-6 m MSL in the eastern part. However, towards the riverbank, the ground is descending. Around the vicinity of the mouth of Sg Gita (Kpg Gita Lama, Kpg Gita Laut and Kpg Gita Tengah), the elevations are the lowest $<4$ m MSL.

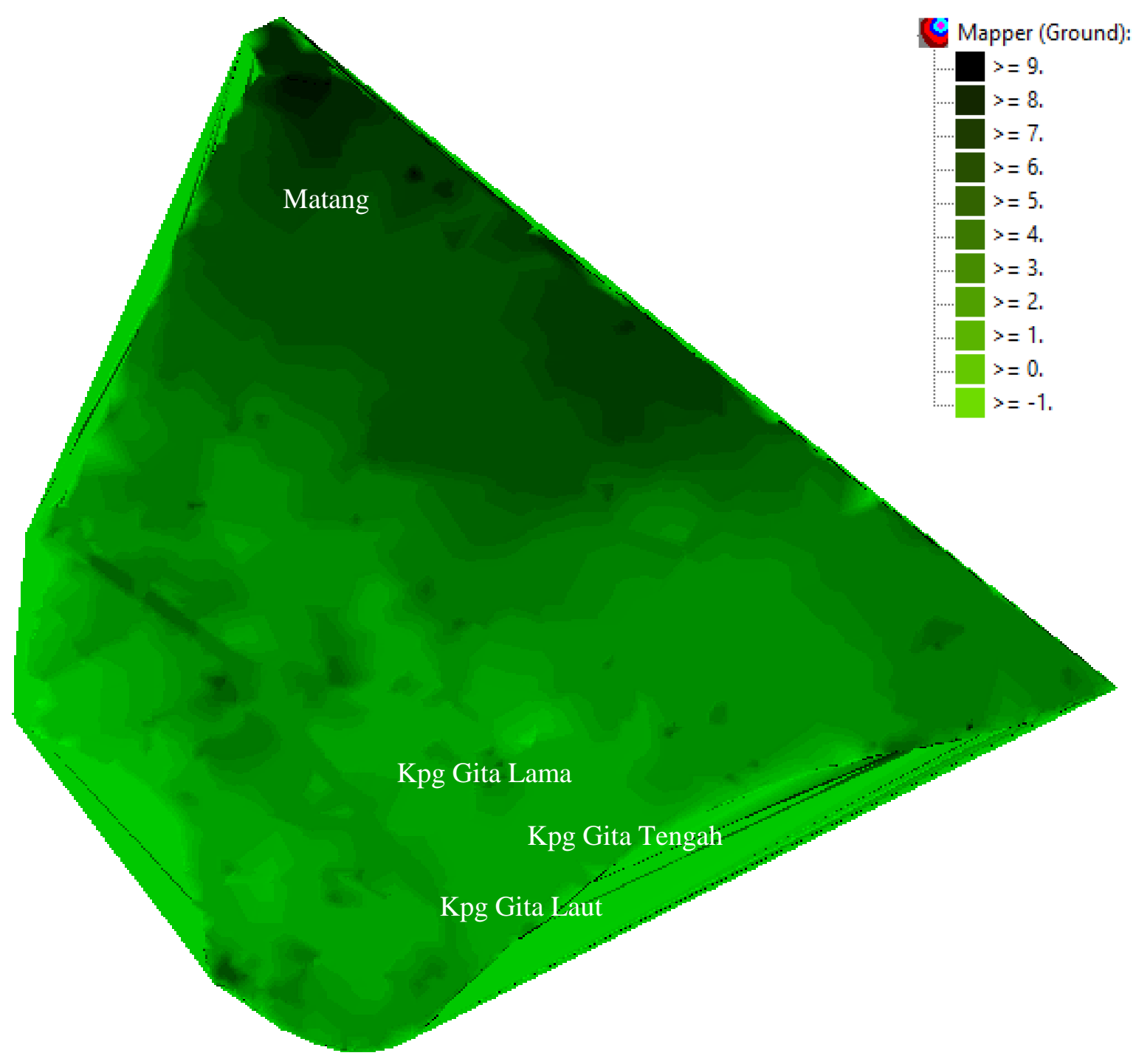

Figure 4. DEM of Sg Gita catchment.

With the assistance of ground model, the exact location of the drains could be identified. Then cross sections are created at the exact survey spots. Demonstrated in Figure 5, the width of a drain could be represented in the Cross Chainage $(\mathrm{m})$ column; while the depth of the drain could be represented in $\mathrm{Z}(\mathrm{m})$ column. $\mathrm{X}(\mathrm{m})$ and $\mathrm{Y}(\mathrm{m})$ columns are the coordinate of the spot. These represent 
the depression on ground surface from which the water would travel into and flow off following the land form.

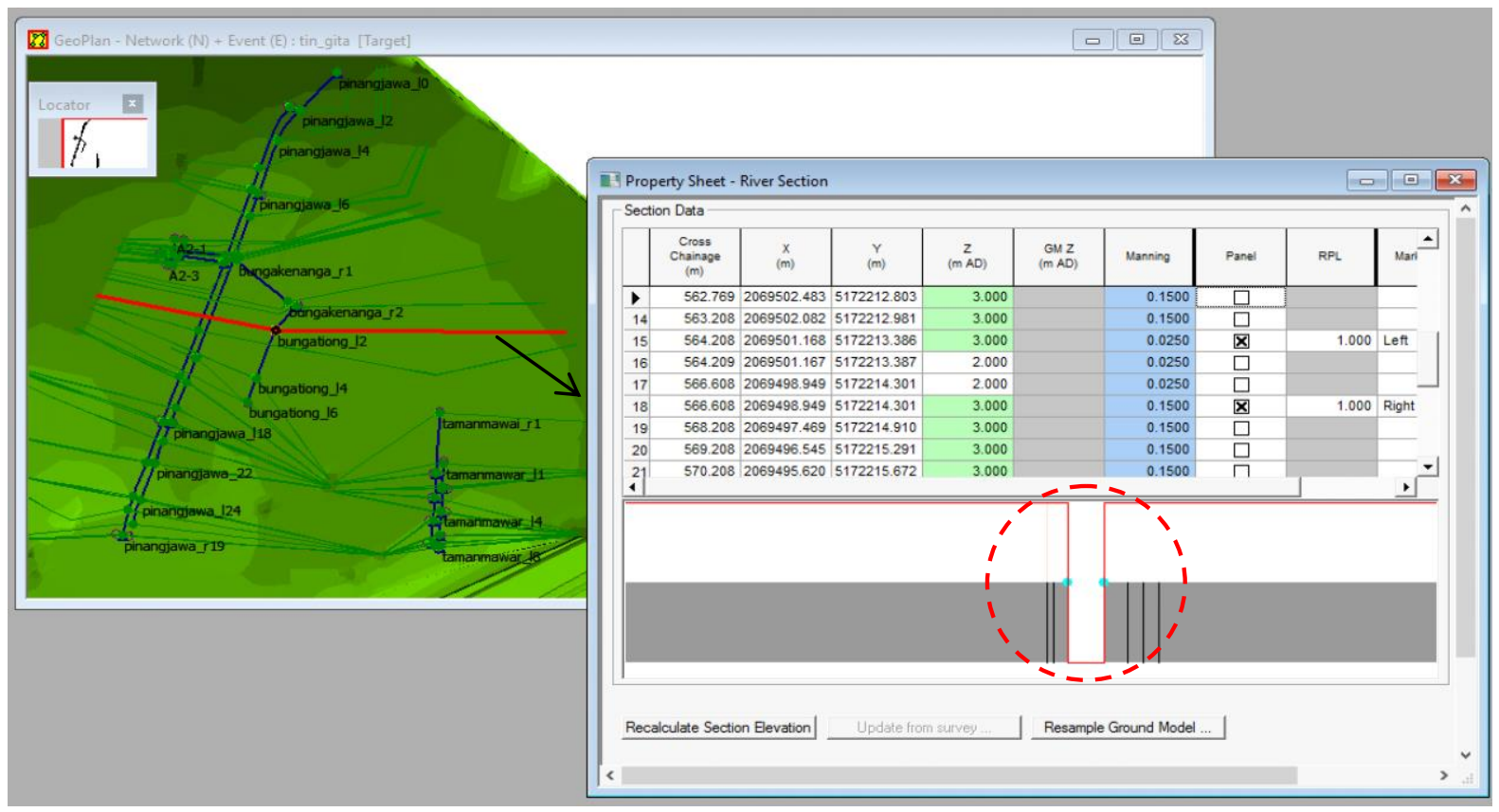

Figure 5. Cross-sectional profile in InfoWorks RS.

\subsection{Flow mechanism}

Recall the previous sections, (Step 1) hourly rainfall are recorded in Table 1; (Step 2) surveyed ground information allows creation of "virtual" drains in InfoWorks environment (see the dotted circle in Figure 5). Next (Step 3), how much water to the drain depends on the sub-catchments.

\subsubsection{Delineation of sub-catchments}

Out of field surveys, the existing drainage network is surveyed of its direction of flow, dimension and network layout. Sg Gita catchment is found to have major drainage / trunk drains on both sides of Jalan Pinang Jawa. Here, they are referred to as Pinang Jawa Left Drain and Pinang Jawa Right Drain. About half of the residential houses have their minor drains flowed to the mentioned trunk drains, and eventually emptied to Sg Sarawak.

The overall drainage catchment is further sub-divided into eleven (11) sub-catchments by tracing their connectedness and outlets. Each of the sub-catchment is a stand-alone network. Referring to Figure 6 below, sub-catchments A1, A2, A3 and A4 are drained to Pinang Jawa Right Drain; while sub-catchment A5, A6 and A8 to Pinang Jawa Left Drain. Sub-catchment A2 is again sub-divided to five (5) smaller catchments due to the fact that the outlets of this catchment, namely Bunga Rampai Right Drain and Bunga Rampai Left Drain are found to be flooded several times previously. Therefore, a much in-depth analysis is carried out for sub-catchment A2.

Sub-catchments A7 and A11 are drained through Bunga Kenanga-Bunga Tiong Drain and discharged directly to Sg Gita. Sub-catchments A9 flow to Taman Mawar Right Drain, while A10 flow to Taman Mawar Left Drain, in which both drains join at the end of drains before being discharged to Sg Sarawak. Similarly, these two sub-catchments are known to be flood prone and therefore they are further sub-divided to accommodate analysis of its drainage system. The area, 
length of overland flow, time of concentration and runoff coefficient for each sub-catchment are tabulated in Table 2 .

\subsubsection{Computation of flows}

HEC-HMS is utilised to compute the flow from each sub-catchment. The loss method and transform method applied in this modelling is SCS Curve Number and SCS Unit Hydrograph respectively. The parameters adopted are shown in Table 3 and the computed flows are checked so that the peak discharges are fit with those obtained from Rational Method. Examples of the flow hydrographs for Sg Gita sub-catchments are presented in Figure 7.
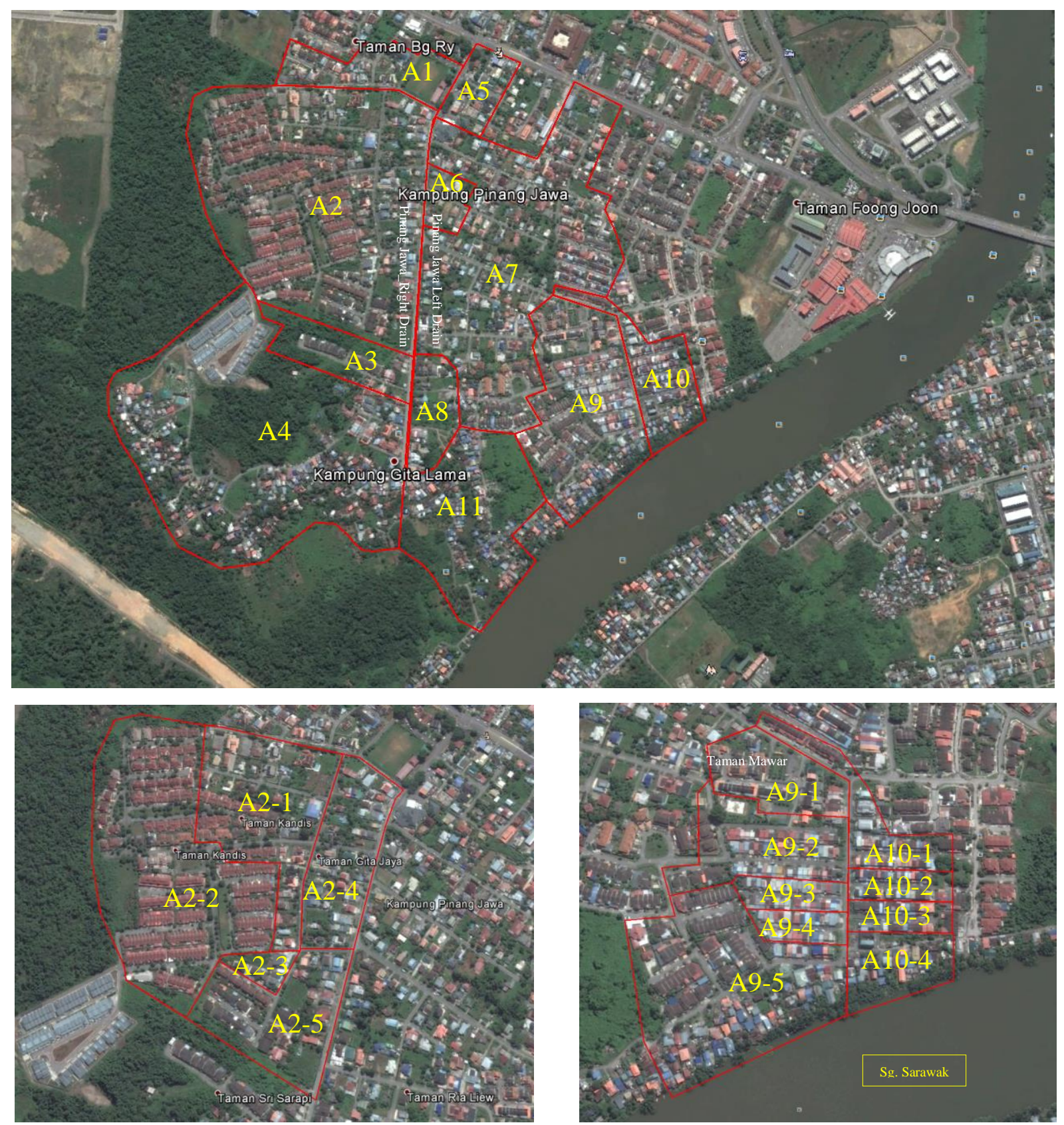

Figure 6. Delineation of Sg Gita sub-catchments.

ISSN: $2289-7771$

Copyright @ 2017 JASPE

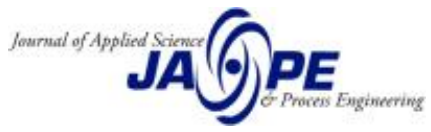


Table 2. Information of Sg Gita sub-catchments

\begin{tabular}{|c|c|c|c|c|c|c|}
\hline $\begin{array}{c}\text { Sub- } \\
\text { Catchment }\end{array}$ & $\begin{array}{c}\text { Area } \\
\left(\mathrm{m}^{2}\right)\end{array}$ & $\begin{array}{c}\text { Length of } \\
\text { Overland } \\
\text { Flow }(\mathrm{m})\end{array}$ & $\begin{array}{c}\text { Time of } \\
\text { Overland } \\
\text { Flow, } \mathrm{t}_{\mathrm{d}} \\
(\mathrm{min})\end{array}$ & $\begin{array}{c}\text { Channel } \\
\text { Flow Time, } \\
\mathrm{t}_{\mathrm{o}}(\mathrm{min})\end{array}$ & $\begin{array}{c}\text { Time of } \\
\text { Concentration, } \mathrm{t}_{\mathrm{c}} \\
(\mathrm{min})\end{array}$ & $\begin{array}{c}\text { Runoff } \\
\text { Coefficient, C }\end{array}$ \\
\hline $\mathrm{A} 1$ & 44113 & 43.0 & 32.464 & 8.875 & 41.339 & 0.80 \\
\hline $\mathrm{A} 2-1$ & 72221 & 10.0 & 19.800 & 13.618 & 33.418 & 0.80 \\
\hline $\mathrm{A} 2-2$ & 132320 & 32.6 & 55.268 & 10.041 & 65.309 & 0.80 \\
\hline A2-3 & 6445 & 10.0 & 1.464 & 4.340 & 5.804 & 0.80 \\
\hline A2-4 & 20012 & 10.0 & 26.619 & 5.626 & 32.245 & 0.80 \\
\hline A2-5 & 28790 & 42.2 & 43.015 & 4.177 & 47.192 & 0.80 \\
\hline A3 & 38664 & 57.0 & 95.099 & 5.088 & 100.187 & 0.48 \\
\hline A4 & 306426 & 106.0 & 116.946 & 38.985 & 155.931 & 0.56 \\
\hline A5 & 24864 & 10.0 & 1.464 & 3.030 & 4.494 & 0.80 \\
\hline A6 & 14860 & 55.1 & 71.977 & 1.754 & 73.731 & 0.80 \\
\hline A7 & 162127 & 10.0 & 1.464 & 12.658 & 14.122 & 0.80 \\
\hline A8 & 28454 & 40.0 & 52.818 & 0.953 & 53.771 & 0.60 \\
\hline A9-1 & 17195 & 10.0 & 1.464 & 24.057 & 25.521 & 0.60 \\
\hline A9-2 & 25473 & 10.0 & 1.464 & 12.572 & 14.036 & 0.80 \\
\hline A9-3 & 7085 & 10.0 & 1.464 & 3.350 & 4.814 & 0.80 \\
\hline A9-4 & 5883 & 10.0 & 1.464 & 2.413 & 3.877 & 0.80 \\
\hline A9-5 & 56402 & 53.2 & 40.083 & 6.796 & 46.879 & 0.80 \\
\hline A10-1 & 15882 & 10.0 & 1.464 & 19.097 & 20.561 & 0.80 \\
\hline A10-2 & 6440 & 10.0 & 1.464 & 2.925 & 4.389 & 0.80 \\
\hline A10-3 & 6579 & 10.0 & 1.464 & 1.678 & 3.142 & 0.80 \\
\hline A10-4 & 133626 & 10.0 & 1.464 & 9.372 & 10.836 & 0.80 \\
\hline A11 & 10356 & 100.6 & 114.925 & 1.641 & 116.566 & 0.55 \\
\hline & & & & & & \\
\hline
\end{tabular}

Table 3. Parameters for SCS hydrograph method

\begin{tabular}{|c|c|c|c|c|c|}
\hline $\begin{array}{c}\text { Sub- } \\
\text { Catchment }\end{array}$ & Area $\left.\mathbf{( k m}^{2}\right)$ & $\begin{array}{c}\text { Initial Abstraction } \\
(\mathbf{m m})\end{array}$ & $\begin{array}{c}\text { Curve } \\
\text { Number }\end{array}$ & $\begin{array}{c}\text { Impervious } \\
(\mathbf{\%})\end{array}$ & $\begin{array}{c}\text { Lag Time } \\
(\mathbf{m i n})\end{array}$ \\
\hline A1 & 0.044130 & 4 & 94 & 80 & 41.30 \\
\hline A2-1 & 0.072210 & 4 & 96 & 90 & 33.40 \\
\hline A2-2 & 0.132320 & 4 & 94 & 90 & 65.30 \\
\hline A2-3 & 0.006445 & 4 & 93 & 70 & 5.80 \\
\hline A2-4 & 0.020012 & 4 & 96 & 90 & 32.25 \\
\hline A2-5 & 0.028790 & 4 & 96 & 90 & 47.00 \\
\hline A3 & 0.038664 & 4 & 89 & 50 & 100.20 \\
\hline A4 & 0.306426 & 4 & 86 & 50 & 155.93 \\
\hline A5 & 0.024864 & 4 & 96 & 90 & 4.49 \\
\hline A6 & 0.014860 & 4 & 94 & 80 & 73.73 \\
\hline A7 & 0.162167 & 4 & 96 & 90 & 14.12 \\
\hline A8 & 0.028454 & 4 & 92 & 60 & 53.74 \\
\hline A9-1 & 0.017195 & 4 & 96 & 90 & 25.52 \\
\hline A9-2 & 0.025473 & 4 & 96 & 90 & 14.04 \\
\hline A9-3 & 0.007085 & 4 & 96 & 99 & 4.81 \\
\hline A9-4 & 0.005883 & 4 & 97 & 99 & 4.81 \\
\hline A9-5 & 0.056402 & 4 & 94 & 80 & 46.88 \\
\hline A10-1 & 0.015882 & 4 & 96 & 90 & 20.56 \\
\hline A10-2 & 0.006440 & 4 & 96 & 90 & 4.84 \\
\hline A10-3 & 0.006579 & 4 & 96 & 90 & 3.14 \\
\hline A10-4 & 0.013626 & 4 & 94 & 80 & 10.84 \\
\hline
\end{tabular}



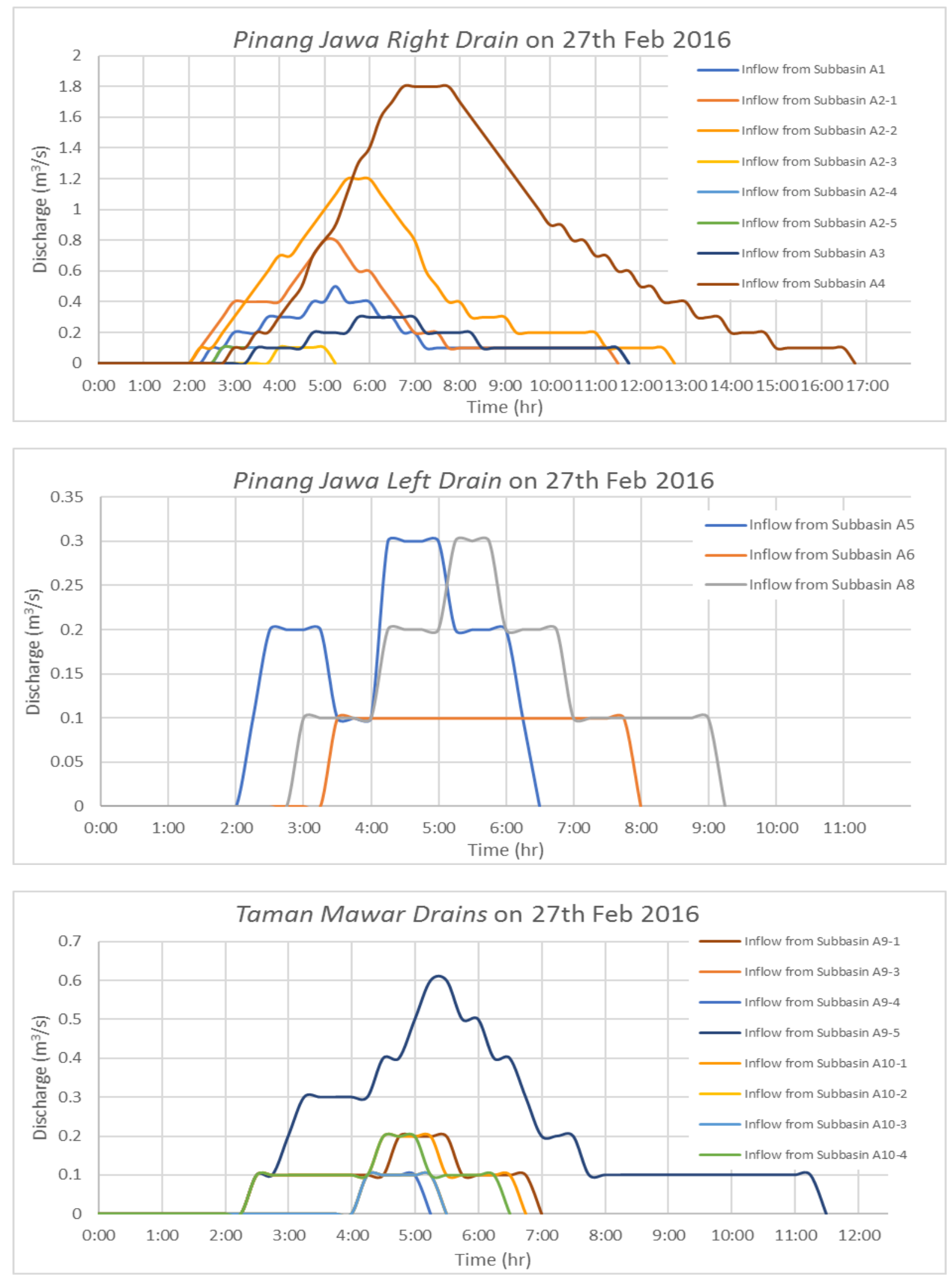

Figure 7. Flow hydrographs due to $27^{\text {th }}$ February 2016 storm event. 


\subsubsection{Drainage network}

Generally, five (5) drainage networks are computed. In the schematic diagram in Figure 8, the trunk drains of Pinang Jawa Left Drain and Pinang Jawa Right Drain are visible on the left. Bunga Kenanga - Bunga Tiong Drain (in the middle) is created to cater for sub-catchment A7 that did not drained to Pinang Jawa drains. Another two networks on the right are named Taman Mawar Right Drain (for sub-catchment A9) and Taman Mawar Left Drain (for sub-catchment A10).

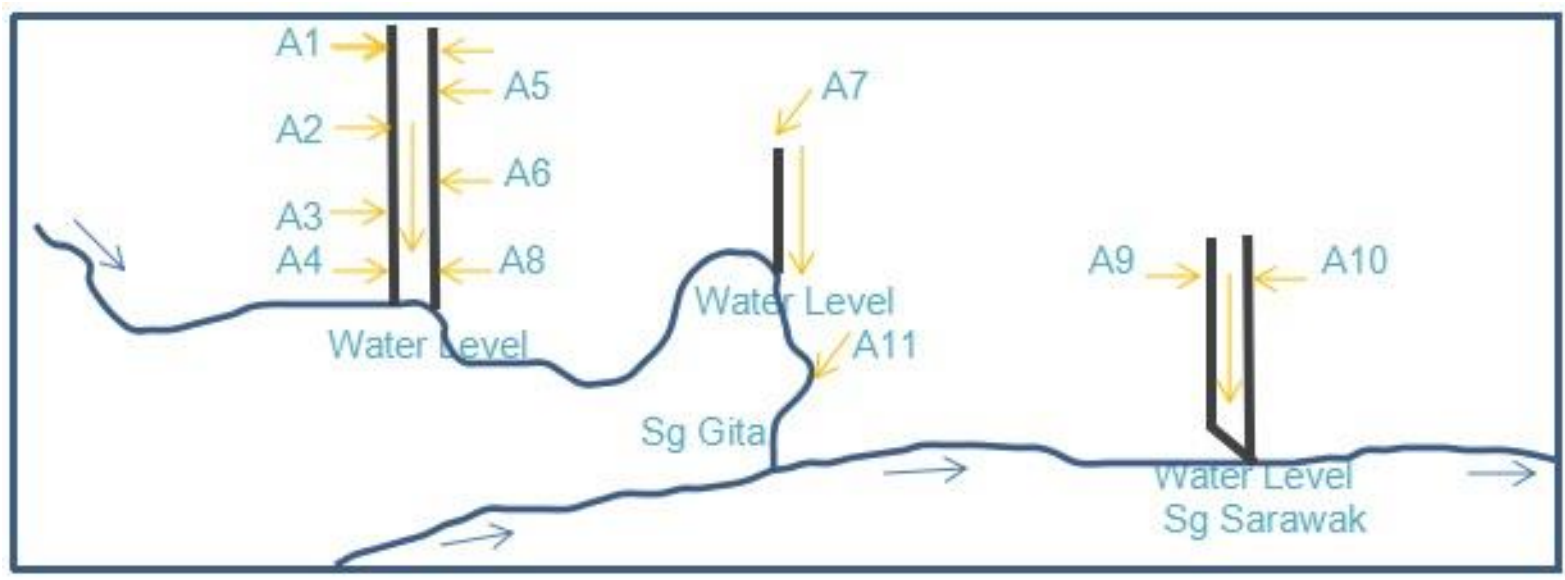

Figure 8. Drainage networks.

\section{Investigative modelling}

\subsection{Control Scenario}

All networks depicted in the previous figure receive waters from its sub-catchments at different points of the urban drains. Eventually the waters flow to the end of the drains that may or may not be obstructed by river water level of Sg Sarawak. Sg Sarawak is not modelled explicitly, but represented as high/low river water levels at the end of drains.

First, as a control, flows within the drain are kept to minimum $\left(1 \mathrm{~m}^{3} / \mathrm{s}\right)$ to compare with the later modelling. Figure 9 below demonstrates the outcome of 1.8m MSL river water level (no bank burst at this level). The model suggests under-sized drain at Location A that caused spill. While the Locations $\mathrm{B}$ and $\mathrm{C}$ together with unnamed patches in the figure suggest low ground levels (lower than drain water level) that the model interprets them as submergence. Keeping the same drain flows, Figure 10 shows the extent of flooding resulting from different river water levels. Source [10] had determined that flood to cause river water level raised to $3 \mathrm{~m} \mathrm{MSL}$ as 2-year return period flood; and 5m MSL as 50 -year return period flood. The figure shows that river water level $>2 \mathrm{~m}$ MSL would have inundated Sg Gita catchment excessively.

\subsection{Scenario of urban flooding}

Continued from the previous scenario, the drain flows are changed to those of $27^{\text {th }}$ February 2016 event derived in Section 3.3.2. The downstream river water level is set to $1.8 \mathrm{~m}$ MSL so that a comparison could be made with Figure 9. Extent of the urban flooding is depicted in Figure 11. It indicates that inundation along Jalan Bunga Kenanga that conforms to the finding from interview with residents. Flooding at Jalan Bunga Rose increases. The rest of the patches are similar to what predicted in Figure 9 that the modellers consider them as outliner. 


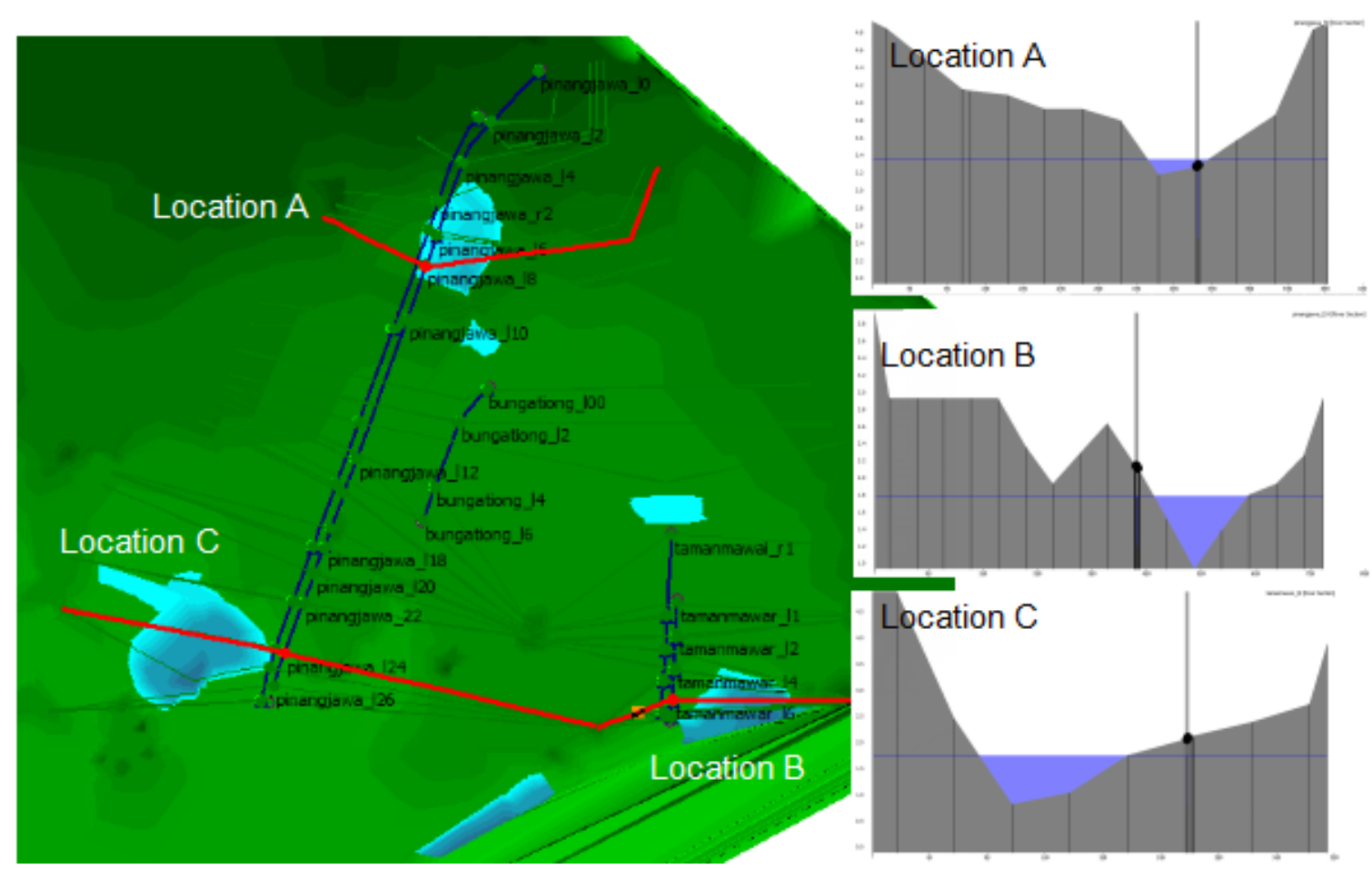

Figure 9. Modelling of 1.8m MSL river water level (no bank burst).

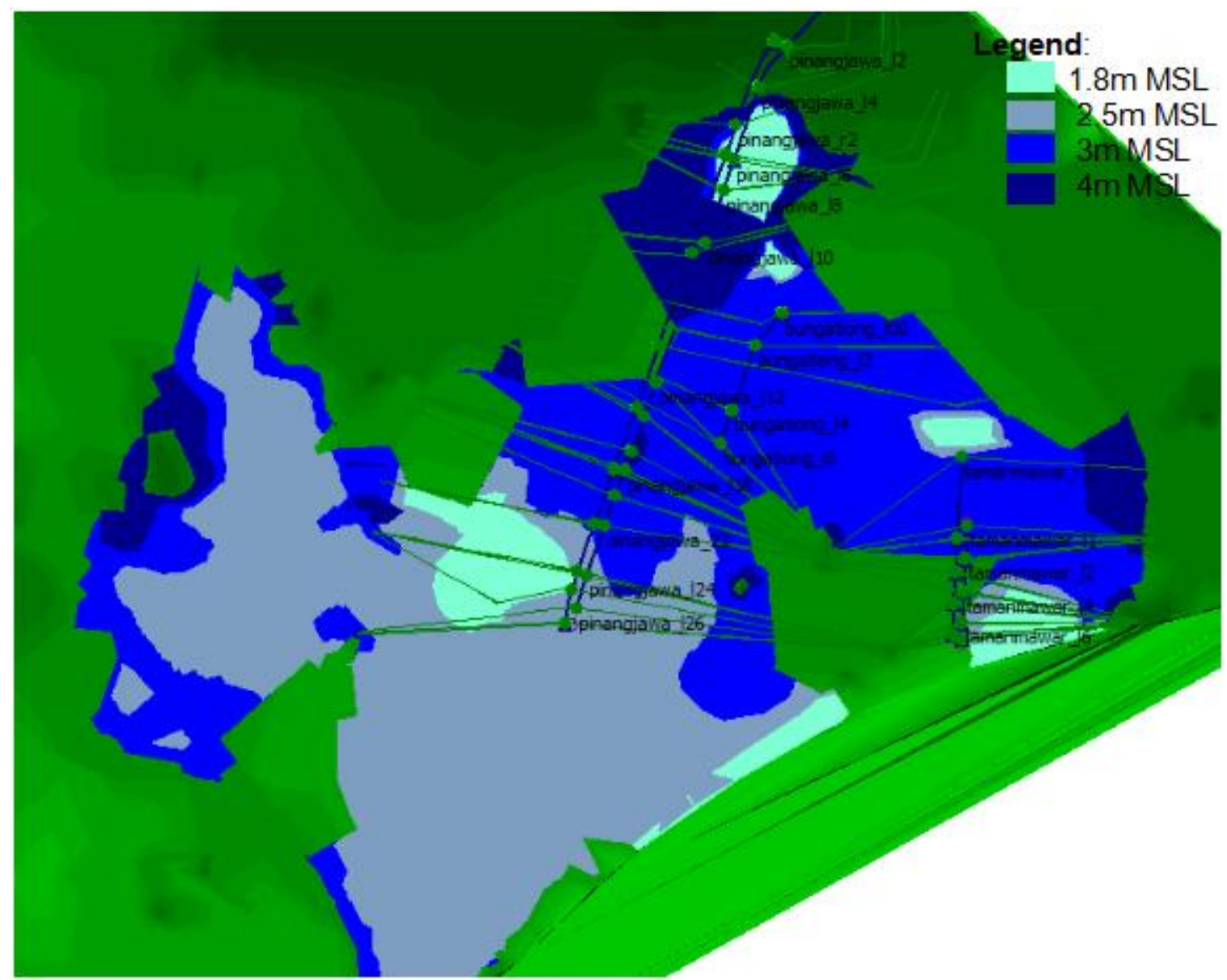

Figure 10. Impacts of river water level to Sg Gita catchment.

ISSN: 2289-7771

Copyright $\odot 2017$ JASPE
Jaurual of Apptied Sience (1) 
However, the model has not predicted any flooding in Jalan Bunga Rampai, in which the residents maintained that flash flood often occur at the juncture. It suggests that should in case of flooding at that location, it could be due to other reason.

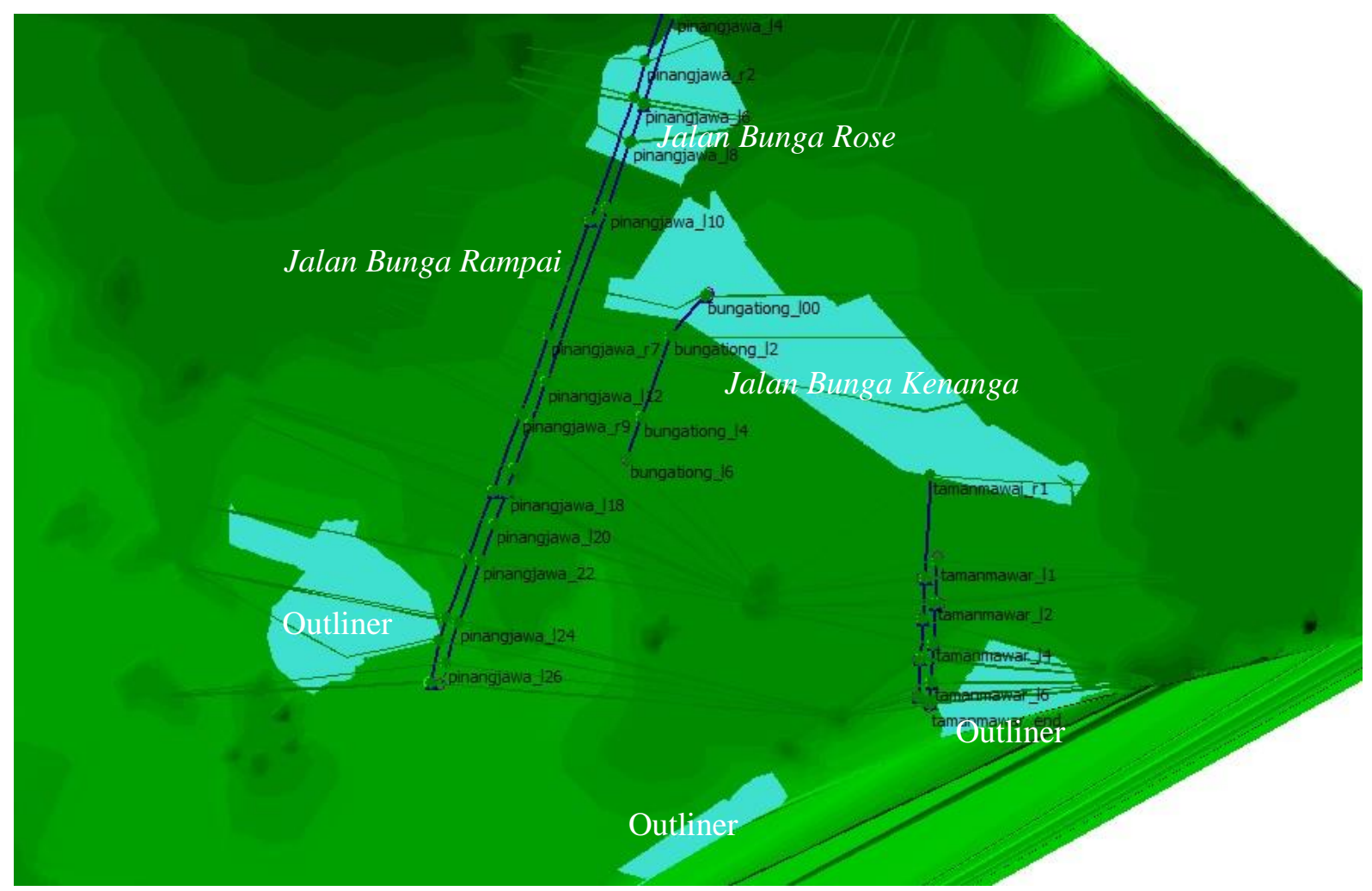

Figure 11. Urban flash flood.

\subsection{Scenario of $27^{\text {th }}$ February 2016 event}

This scenario represents the drain flows of $27^{\text {th }}$ February 2016 event collided with the actual river water level during the event reaching 3m MSL. The resulted flood map for Sg Gita catchment is presented in Figure 12. However, it should be noted that the model are synthetic by nature and could not be calibrated. No record of the actual drain flow is available. By practice, the relatively constant shapes of the urban drains enable acceptable flow estimation. Yet, the model could be verified with field flood depth obtained through interview with the residents. Four (4) locations are identified and the comparisons are tabulated in Table 4 . The model is found to be able to reconstruct reasonably well of the flooding event.

It should be noted that the flood extent in the figure below has a major portion of it produced by high river water level ( $3 \mathrm{~m} \mathrm{MSL}$ ) (as in Figure 10). It can be deduced that the flooding was majorly of river flooding from adjacent $\mathrm{Sg}$ Sarawak that had filled up much of the capacity of the drains. This explains the flooding at Jalan Bunga Rampai.

The intense rain storm had worsened the low laying areas further. One infamous photo depicted in the local newspapers as well as in neighbouring Brunei and Singapore (inset below) shows a frowning pak cik in the thigh-deep flood water (about a meter) in Jalan Pinang Jawa. Our model could get the same flood depth in the same location. 


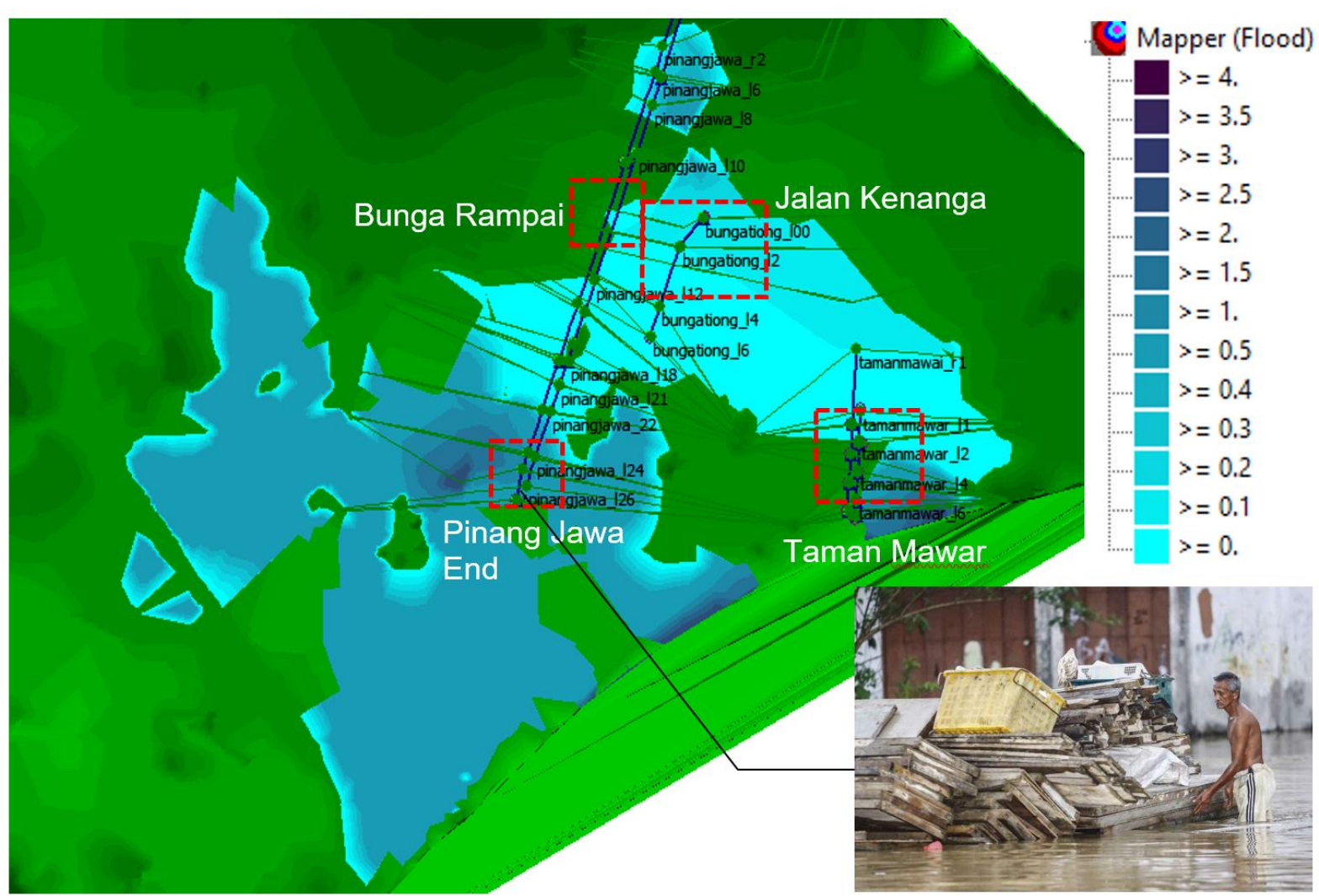

Figure 12. Flood mapping of $27^{\text {th }}$ February 2016 event.

Table 4 . Verification of $27^{\text {th }}$ February 2016 event

\begin{tabular}{|l|c|c|c|}
\hline Location & $\begin{array}{c}\text { Computed Flood Depth } \\
(\mathrm{mm})\end{array}$ & $\begin{array}{c}\text { Field Flood Depth } \\
(\mathrm{mm})\end{array}$ & Remarks \\
\hline Jalan Bunga Rampai & $200-300$ & 200 & Matched \\
\hline Jalan Kenanga & $100-200$ & 300 & Close \\
\hline Taman Mawar & $100-500$ & 300 & Close \\
\hline Pinang Jawa End & 1000 & 1000 & Matched \\
\hline
\end{tabular}

How the flood water over-spilled the drains is not clear in the flood map. Therefore, long section profiles would be a better medium to enlighten the matter. Table 5 demonstrates four drains, from which they reinstate that high river water level has caused backwater in most drains. Pinang Jawa Drains are overwhelmed and an upgrade of its capacity is suggested.

\section{Conclusion}

A reconstruction of historical extreme event in Sg Gita catchment has allowed investigation into the causes of flooding in the area. It allows what-if scenarios that could not be done in real life. Ground surface runoff alone could cause small impact to Sg Gita catchment. River water level on the other hand, is found to be the culprit of extensive flooding. With this model, it shows flow routing with inclusion of downstream river water level explain well the flooding of an urban catchment with lined urban drainage and bounded by a downstream river. Conventional urban drainage model with only flow routing is found inadequate to represent the said catchment condition. 
Table 5. Long section profiles with identified problems

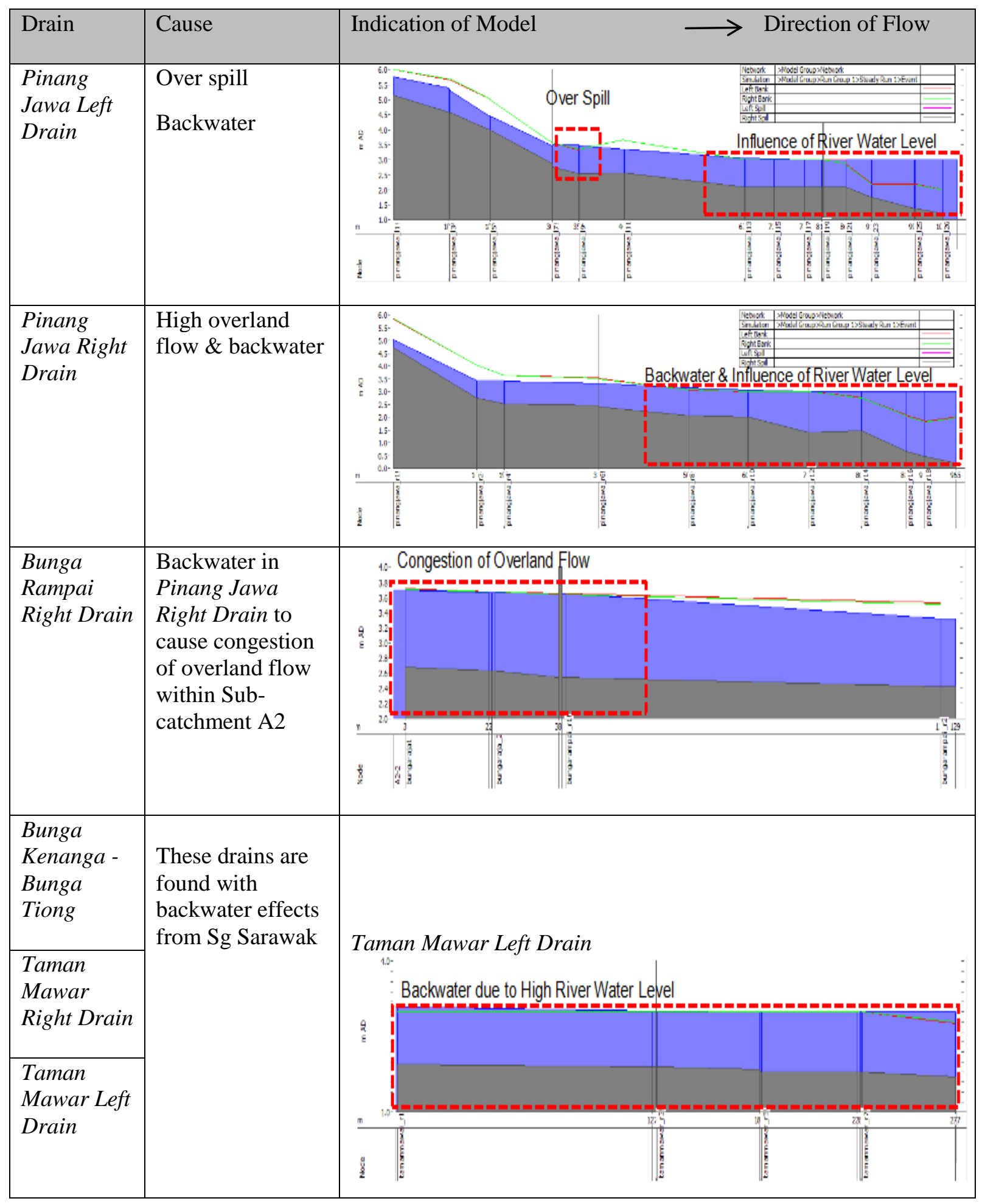

\section{Acknowledgement}

The authors are thankful to the Department of Irrigation and Drainage (DID) Sarawak for their supports. 


\section{References}

[1] Jenny, K.K., Mah, D.Y.S., Putuhena, F.J., and Said, S. (2007). Post-Flood Forensic Analysis of Maong River Using Infoworks River Simulation (RS). The Journal of Institution of Engineers Malaysia, Vol. 68, No. 4, 41-46.

[2] Said, S., Mah, D.Y.S. Mah, Sumok, P., and Lai, S.H. (2009). Water Quality Monitoring of Maong River, Malaysia. Proceedings of the Institution of Civil Engineers - Water Management, Vol. 162, No. 1, 35-40.

[3] Mah, D.Y.S., Lai, S.H., Chan, R.A., and Putuhena, F.J. (2012). Investigative Modelling of the Flood Bypass Channel in Kuching, Sarawak by Assessing its Impact on the Inundations of Kuching-Batu Kawa-Bau Expressway. Structure and Infrastructure Engineering, Vol. 8, No. 7, 705-714.

[4] Department of Irrigation and Drainage (DID) Sarawak (2013). Proposed Drainage Improvement Works at Kpg Gita.

[5] Winsemius, H.C., Aerts, J.C., van Beek, L.P., Bierkens, M.F., Bouwman, A., Jongman, B., Kwadijk, J.C., Ligtvoet, W., Lucas, P.L., van Vuuren, D.P., and Ward, P.J. (2016). Global Drivers of Future River Flood Risk. Nature Climate Change, Vol. 6, No. 4, 381-385.

[6] Sharp, J.J., and Lim, Y.H. (2000). The Sarawak River barrage - Hydrotechnical and Geotechnical Aspects. Proceedings of the Institution of Civil Engineers - Water, Maritime and Energy, Vol. 142, 87-96.

[7] Mukolwe, M.M., Yan, K., Di Baldassarre, G., and Solomatine, D.P. (2015). Testing New Sources of Topographic Data for Flood Propagation Modelling under Structural, Parameter and Observation Uncertainty. Hydrological Sciences Journal, Vol. 61, No. 9, 1707-1715.

[8] Department of Irrigation and Drainage (DID) Sarawak (2016). Flood Report for Kuching in February 2016.

[9] Zamudio, J., Haynie, T., Anderson, L., Gasiewski, A., Dai, E., Stachura, M., Elston, J., Stoll, J., Walker, B., Gordon, R., and Wilson, M. (2015). Drones in Geophysics. Symposium on the Application of Geophysics to Engineering and Environmental Problems 2015, pp. 105-112.

[10] Jurutera Jasa (1999). Sg Sarawak Flood Mitigation Options Study. 